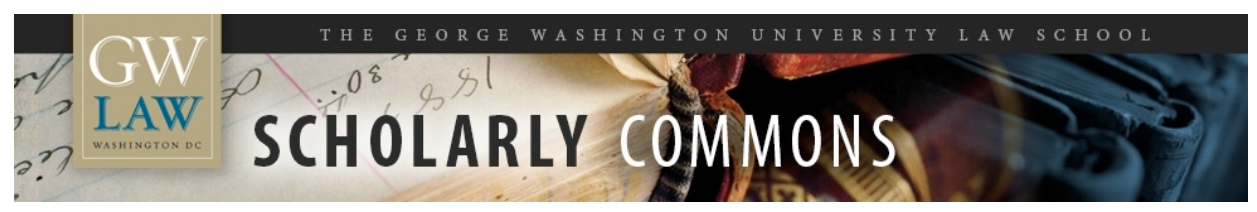

\title{
Law School Clinics and the Untapped Potential of the Court Watch
}

Jessica K. Steinberg

George Washington University Law School, steinberg@law.gwu.edu

Follow this and additional works at: https://scholarship.law.gwu.edu/faculty_publications

Part of the Law Commons

\section{Recommended Citation}

Steinberg, Jessica, Law School Clinics and the Untapped Potential of the Court Watch (2018). GWU Law School Public Law Research Paper No. 2018-44; GWU Legal Studies Research Paper No. 2018-44. Available at SSRN: https://ssrn.com/abstract $=3260876$

This Article is brought to you for free and open access by the Faculty Scholarship at Scholarly Commons. It has been accepted for inclusion in GW Law Faculty Publications \& Other Works by an authorized administrator of Scholarly Commons. For more information, please contact spagel@law.gwu.edu. 


\title{
Law School Clinics and the Untapped Potential of the Court Watch
}

\author{
Jessica K. Steinberg*
}

\section{INTRODUCTION}

This is a time of enormous creativity and innovation in civil access to justice. It is now widely recognized that scarcity is a reality in the provision of legal services and that overburdened and technologically retrograde courts are struggling to meet the demands of case processing in a fair and efficient manner. ${ }^{1}$ Growing awareness of the "justice gap" between poor and wealthy court users has launched a wave of new access to justice interventions. ${ }^{2}$ In recent years, legal services providers, courts, and regulatory bodies have all been engaged in the effort to innovate. The provider community has been forced to stretch its capacity by experimenting with hotlines, "unbundled" legal services, and attorney-of-the-day models. ${ }^{3}$ Court actors have worked to improve access to justice by developing self-help centers, ${ }^{4}$ standardizing pleadings, ${ }^{5}$ and implementing ombudsman-like programs that liaise with lay parties. ${ }^{6}$ And regulatory bodies have begun to relax judicial ethics rules to allow for greater engagement with the unrepresented ${ }^{7}$ and to license non-lawyers to handle certain types of cases. ${ }^{8}$

Accompanying the proliferation of various interventions is a growing call for empirical research on civil access to justice. In medicine, evidence-based protocols have been the hallmark of disease prevention and treatment for more than fifty years. Legal interventions, by contrast, continue to be adopted and implemented primarily on the basis of instinct. Scholars and policymakers are increasingly cognizant of the

* Jessica K. Steinberg, Associate Professor of Clinical Law, George Washington University Law School. My deepest gratitude goes to Victor Quintanilla and the Indiana Journal for Law \& Social Equality for convening a timely and inspiring symposium on the intersection of legal education, access to justice, and service learning. I am also grateful to Colleen Shanahan and Anna Carpenter for thoughtful feedback. For outstanding research assistance, I thank Esna Abulamit, AJ Bolan, and Elenore Wade.

1 See Benjamin H. Barto, Against Civil Gideon (and for Pro Se Court Reform), 62 FLA. L. REV. 1227, 1227-28, 1230-31, 1233, 1255, 1273 (2010); Jessica K. Steinberg, In Pursuit of Justice? Case Outcomes and the Delivery of Unbundled Legal Services, 18 Geo. J. ON PoverTy L. \& PoL'Y 453, 453-54 (2011); Jessica K. Steinberg, Demand Side Reform in the Poor People's Court, 47 ConN. L. REv. 741, 765 (2015).

2 See Laura K. Abel, Evidence-Based Access to Justice, 13 U. PA. J.L. \& Soc. Change 295, 296 (2010).

3 Steinberg, Demand Side Reform, supra note 2, at 765.

4 See ABA Standing Comm. on the Delivery of Legal Services, The Self-Help Center Census: A National Survey, 1 (Aug. 2014), https://www.americanbar.org/content/dam/aba/administrative/delivery_legal_ services/ls_del_self_help_center_census.authcheckdam.pdf.

5 See A Supplemental Report to the Supreme Court of Texas on the Texas Access to Justice Commission's Self-Represented Litigants Committee and Subcommittees, TeXas ACCEss to Justice Commission (Feb. 6, 2012), http://www.texasatj.org/sites/default/files/SupplementalSRLReporttoCourt020612.pdf.

6 Rebecca L. Sandefur \& Thomas M. Clarke, Am. Bar Found. \& Nat'L Ctr. State Courts, Roles BEYOND LAWYERS: SUMMARY, RECOMMENDATIONS AND RESEARCH REPORT 16 (2016).

7 See Model Code of Jud. Conduct Canon 2, r. 2.2 cmt. n.4 (2007).

$8 \quad$ Wash. State Ct. Admission to Practice R. 28 (2017). 
need for an active research agenda to answer important questions about how best to modify the civil justice infrastructure and the delivery of legal services. Empirically tested metrics are essential to developing effective protocols, detecting the unintended consequences of a particular intervention, refining and improving upon existing practices, and assisting in scaling the most successful new models.

Recently, the idea that law school clinics might serve as sites or architects of a civil justice research agenda has been advanced. Jeffrey Selbin and Jeanne Charn have put forward an innovative proposal suggesting that law school clinics should serve as the site for empirical access to justice research. ${ }^{9}$ Indeed, clinics are wellpositioned to play such a role: they have access to client communities, can frame relevant research questions, and are often situated within larger research institutions that have connections to social scientists who can design and implement studies. ${ }^{10}$ Law school clinical programs have long been devoted to the twin goals of pedagogy and social justice, but the notion that research might be a third arm of their mission is also now gaining currency. ${ }^{11}$

Building on Selbin and Charn's proposal, this Article suggests that "court watch" projects may serve as ideal points of entry into research for law school clinics. Although the term "court watch" is colloquial, it refers to a serious form of research taking place in a naturally occurring environment: the courtroom. The unit of study is typically the individual case hearing, although collateral interactions among court actors may be of interest as well, and observers are trained to record both qualitative and quantitative data in a formal collection instrument. Much civil justice research relies on interviews and the retrospective review of written court opinions or case documents. While there is much to learn through these methods, there are also many access to justice research questions that can only be evaluated through field observation. ${ }^{12}$ Court watch projects can advance our understanding of important issues such as judicial behavior, litigant capacity, the role of procedure in decision making, the role of counsel, and the divide between the law on the books and the law in action. These are matters which do not lend themselves to study through written documents and for which direct observation is far more critical to effective evaluation than are regression models.

A court watch project can make a unique contribution to research. Field data can inform policy changes, lead to rule revisions, and influence funding decisions on access to justice interventions. Access to justice commissions, which have been created in most states, are charged with developing proposals to identify and address the legal needs of low- and middle-income individuals and may be open to data that informs their efforts. ${ }^{13}$ Legislatures are also increasingly sophisticated in their

\footnotetext{
9 Jeanne Charn \& Jeffrey Selbin, The Clinic Lab Office, 2013 WIS. L. REV. 145, 146, 161 (2013).

10 See id. at 162.

11 See id. at 162-63, 166-67; Colleen F. Shanahan, Jeff Selbin, Alyx Mark, Anna E. Carpenter, Measuring Law School Clinics, 92 Tulane L. Rev. 547, 551-59 (2018).

12 Anna E. Carpenter, Jessica K. Steinberg, Colleen F. Shanahan, \& Alyx Mark, Studying the 'New' Civil Judges, Wis. L. Rev. (forthcoming 2018).

13 ABA Resource Ctr. For Access to Just. Initiatives, State Access to Just. Commissions: Creation, COMPOSITION, AND FURTHER DETAILs (2017), https://www.americanbar.org/content/dam/aba
} 
appetite for and use of data to sharpen and implement policy priorities. ${ }^{14}$ Data-driven policy advocacy squarely fits within law school clinics' service mission ${ }^{15}$ and also dovetails with growing efforts at universities nationwide to engage in communitybased research that builds knowledge and serves a community need. ${ }^{16}$

Additionally, a court watch project can yield pedagogical as well as research benefits. Incorporating a court watch project into a law school clinic offers the potential to impart four unique pedagogical lessons to students. First, a court watch instills the professional value of service by exposing students to a broad swath of justice issues. Second, observations of courtroom actors can acculturate law students to the norms and habits of lawyers and judges, much in the way that the "see one" pedagogy of medical schools promotes observation of a procedure prior to performing it. Third, field research develops the context necessary for clinic students to interrogate the nature and purpose of their individual client work in a deeper manner. And finally, court watch projects offer a method for teaching students, in an experiential manner, how to critique and design institutional systems.

Part I of this Article discusses the need for civil justice research in light of the environment of scarcity and the current climate of innovation. Part II explores proposals to situate empirical research within law school clinics and considers how research might be seen as a complementary arm of clinics' core teaching-service mission. Part III "rediscovers" the court watch as a methodologically appropriate and effective vehicle for law school clinics to engage in data collection, and it examines the research, advocacy, and pedagogical benefits of such an agenda. Finally, Part IV describes a court watch project undertaken by the law school clinic I direct at The George Washington University Law School, evaluating both the promise and challenges of the model in context.

\section{The NeEd For Civil Justice ReSeARCH}

We are in the throes of a renaissance in civil access to justice activity. New models of service delivery and adjudication are rapidly proliferating with an eye toward meeting the enormous needs of individuals with civil justice problems. Trends in civil justice innovation favor an increasing reliance on technology to disseminate

/administrative/legal_aid_indigent_defendants/ATJReports/atjcommissions_structure2017.authcheckda m.pdf.

See Stout Risius Ross, Inc., The Financial Cost and Benefits of Establishing a Right to Counsel in Eviction ProceEdings Under InTRo 214-A, 6 (2016) (report found provision of counsel would give the City a net benefit of $\$ 320$ million annually) (report created for the Pro Bono \& Legal Services Committee of the NYC Bar Association). See also Testimony of New York State Senator Brad Hoylman In Support of Intro 214-A and a Right to Counsel for Low-Income Tenants at Risk of Eviction (Sept. 26, 2016), https://www.nysenate.gov/sites/default/files/hoylman_right_to_counsel_testimony.pdf (referencing Stout Risius Ross Report); Testimony of Anthony Thomas, Political Director, New York City Central Labor Council, AFL-CIO (Sept. 26, 2016).

15 Charn \& Selbin, supra note 9, at 163.

16 See Kerry Strand et al., Principles of Best Practice for Community-Based Research, 9 Mich. J. COMMUnity SERV. LEARNING 5 (2003). 
information and advice, 17 a more active judiciary trained to engage with pro se parties, ${ }^{18}$ and models of service delivery that fall short of full representation. ${ }^{19}$ There has been substantial growth in the development of self-help forms, ${ }^{20}$ court navigator positions, ${ }^{21}$ "unbundled" legal services, ${ }^{22}$ the licensing of non-lawyers to handle certain types of cases, ${ }^{23}$ and revisions to judicial ethics rules. ${ }^{24}$ State courts, judges, and legal services providers are, together and independently, working to improve the handling of civil justice disputes in ways that are both effective and efficient.

As experimentation with various interventions accelerates, the call for empirical access to justice research has grown louder. Jeffrey Selbin and Jeanne Charn decry our lack of critical data on "the legal needs of the poor and the services provided to them," noting that such data gaps would be "unthinkable in other major social policy arenas." 25 Laura Abel proposes specific outcome- and process-based metrics for assessing the value of particular interventions, arguing that shared understandings of efficacy may promote the generalizability of research. ${ }^{26}$ Catherine Albiston and Rebecca Sandefur emphasize the importance of casting a wide net in designing an access to justice research agenda. While they acknowledge that measuring case outcomes is important, they urge a broader exploration of whether the courts are the appropriate or preferred vehicle for resolving community disputes. ${ }^{27}$ These scholars and others promote the undeniably important task of developing practices based on sound and sophisticated studies. ${ }^{28}$

A number of government entities also endorse the need to develop evidencebased practices. The Department of Justice now houses an Office for Access to Justice, which includes as part of its mission the advancement of "research on innovative strategies to close the gap between the need for, and the availability of, quality legal assistance." 29 The Legal Services Corporation, which sets policy and distributes

17 Barton, supra note 2, at 1273.

18 Anna E. Carpenter, Judges and Access to Justice, 93 NoTRE DAME L. REV. 647 (2017).

19 Steinberg, In Pursuit, supra note 2, at 453-54.

20 D. James Greiner, Dalié Jiménez, \& Lois R. Lupica, Self-Help, Reimagined, 92 IND. L.J. 1119,1123

(2017) ("Practically every state court system and legal aid organization has websites providing forms or other information to unrepresented litigants.").

See SANDEFUR \& ClARKE, supra note 6 , at 3-4.

Steinberg, In Pursuit, supra note 2, at 453-54.

See SANDEFur \& ClaRke, supra note 6, at 5; Anna E. Carpenter, Alyx Mark, Colleen F. Shanahan, Trial and Error: Lawyers and Nonlawyer Advocates, 42 LAW \& SOC. INQUIRY (2017). Jessica K. Steinberg, Adversary Breakdown and Judicial Role Confusion in 'Small Case' Civil Justice, BYU L. Rev. 899, 899, 904, 926, 932 (2016).

Charn \& Selbin, supra note 9 , at 155.

Abel, supra note 1, at 299.

Catherine R. Albiston \& Rebecca L. Sandefur, Expanding the Empirical Study of Access to Justice, Wis. L. REv. 101, 105, 114-19 (2013). See also Anna E. Carpenter, Jessica K. Steinberg, Colleen F.

Shanahan, and Alyx Mark, Studying the 'New' Civil Judges, WIS. L. REV. (forthcoming 2018).

See Jeffrey Selbin, Jeanne Charin, Anthony Alfieri, \& Stephen Wizner, Service Delivery, Resource Allocation, and Access to Justice: Greiner and Pattanayak and the Research Imperative, 122 YALE L.J. ONLINE 45, 53 (2012); Jeanne Charn, Celebrating the "Null” Finding: Evidence-Based Strategies for Improving Access to Legal Services, 122 YALE L.J. 2206, 2232 (2013). 
federal funding for legal services nationally, defines as one of its priorities the development of "robust assessment tools" to identify and replicate best practices in the delivery of civil legal assistance. ${ }^{30}$ And in 2015, the Obama Administration launched the White House Legal Aid Interagency Roundtable to coordinate service delivery, improve access to justice, and "advance relevant evidence-based research, data collection, and analysis." 31

A number of new studies have been undertaken in response to the heightened attention to civil access to justice, but empirical research on these issues is still nascent. James Greiner conducted a series of high-profile randomized experimental trials on the impact of representation in various settings, attacking one of the most fundamental and central questions in civil justice administration: Does a lawyer make a difference? ${ }^{32}$ His work evokes the earlier research of Carroll Seron, who also implemented a randomization scheme to test the impact of attorney assistance in housing matters. ${ }^{33}$

Beyond the binary question of whether attorneys improve outcomes, studies have looked at the nuances of how and why representation matters. In a metaanalysis of seventeen studies encompassing 18,000 adjudicated civil cases, Rebecca Sandefur discovered that lawyers' impact is greatest in adversarial forums with the greatest procedural complexity. She attributed this finding, in part, to the attorney's "relational expertise," which she defines as the skill of "negotiating the interpersonal environments in which professional work takes place." ${ }^{4}$ Building on Sandefur's analysis, Colleen Shanahan, Anna Carpenter, and Alyx Mark parsed through case documents in 5,000 unemployment compensation matters to demonstrate that an attorney's strategic expertise is also critical to understanding outcomes. ${ }^{35}$ Their study found that, although attorney representation is positively correlated to favorable

30 Legal Services Corporation, Strategic Plan 2012-2016 (Oct. 2012), https://www.lsc.gov/sites/default/files/LSC/lscgov4/LSC_Strategic_Plan_2012-2016--

Adopted_Oct_2012.pdf.

31 Presidential Memorandum-Establishment of the White House Legal Aid Interagency Roundtable, White House Office of the Press Secretary (Sept. 24, 2015), https://obamawhitehouse.archives.gov/the-press-office/2015/09/24/presidential-memorandumestablishment-white-house-legal-aid-interagency. D. James Greiner \& Cassandra Wolos Pattanayak, Randomized Evaluation in Legal Assistance: What Difference Does Representation (Offer and Actual Use) Make?, 121 YALE L.J. 2118, 2118, 2122 (2012); D. James Greiner, Cassandra Wolos Pattanayak, \& Jonathan Hennessy, The Limits of Unbundled Legal Assistance: A Randomized Study in a Massachusetts District Court and Prospects for the Future, 125 HARV. L. REV. 901, 903 (2013).

33 See Carroll Seron, Gregg Van Ryzin, \& Martin Frankel, The Impact of Legal Counsel on Outcomes for Poor Tenants in New York City's Housing Court: Results of a Randomized Experiment, 35 LAW \& Soc'Y REV. 419, 419 (2001).

34 Rebecca L. Sandefur, Elements of Professional Expertise: Understanding Relational and Substantive Expertise through Lawyer's Impact, 80 Am. Soc. Rev. 909, 924 (2015).

35 Colleen F. Shanahan, Anna E. Carpenter, \& Alyx Mark, Lawyers, Power, and Strategic Expertise, 93 DeNV. L. REv. 469, 469 (2016). In addition to demonstrating attorney strategic expertise, this data set illuminated differences in the use of procedures by lawyers and nonlawyer advocates, see Anna E. Carpenter, Alyx Mark, Colleen F. Shanahan, Trial and Error: Lawyers and Nonlawyer Advocates, 42 LAW \& Soc. INQUIRY (2017), and evaluated the comparative advantages of representation by lawyers and law students, see Colleen F. Shanahan, Jeff Selbin, Alyx Mark, Anna E. Carpenter, Measuring Law School Clinics, 92 Tulane L. Rev. 547 (2018). 
outcomes, some attorneys made strategically unwise choices about the use of particular procedures in ways that accrued to the disadvantage of their clients. ${ }^{36}$

Attorney assistance that falls short of full representation has also been a subject of recent research. "Unbundled" legal services, a "piecemeal lawyering model in which a lawyer provides assistance with a discrete legal task only" is now the dominant form of service delivery offered by legal aid offices nationwide. ${ }^{37}$ One set of studies has compared case outcomes achieved by individuals receiving unbundled assistance to those achieved by individuals with both full representation and no representation, ${ }^{38}$ finding that the provision of unbundled aid does not improve outcomes on most metrics ${ }^{39}$ and may even risk harm to low- and middle-income litigants by slowing the pace of law reform. ${ }^{40}$ In a second group of studies, researchers have evaluated the subjective experiences of litigants who receive unbundled aid, registering high levels of satisfaction with the services provided. ${ }^{41}$ Together, these studies raise an important question about our access to justice goals in offering unbundled aid: Are we advancing procedural justice at the expense of substantive justice and is that our intent? Studies have also considered the quality and neutrality of unbundled legal services and the assistance offered by other self-help providers. ${ }^{42}$

Only a handful of studies have examined local courtroom dynamics through field observation. In research utilizing a range of methodologies-including focused ethnography, ${ }^{43}$ linguistic analysis, ${ }^{44}$ and case studies ${ }^{45}$-field observation has been employed to study judicial conduct through the lens of gender, race, and poverty. A particular focus of this work has been the exercise and bounds of judicial discretion and its relationship to litigant voice, substantive law, and outcomes. ${ }^{46}$ The operation

$36 \quad$ Id. at 469-70, 508-10.

$37 \quad$ Steinberg, In Pursuit, supra note 2, at 454.

38 See Steinberg, In Pursuit, supra note 2, at 457, 474; UCLA School of LaW, Evaluation of the Van Nuys Legal Self-Help Center Final RePort 3 (Aug. 30, 2001) [hereinafter Van Nuys] http://www.courts.ca.gov/partners/documents/Final_Evaluation_Van_Nuys_SHC2001.doc.

39 See Steinberg, In Pursuit, supra note 2, at 453-44; Van Nuys, supra note 37, at 12-13.

40 Colleen F. Shanahan, Anna E. Carpenter, \& Alyx Mark, Can a Little Representation be a Dangerous Thing?, 67 HASTINGS L.J. 1367, 1376-77 (2016).

41 See Marsha M. Mansfield, Litigants Without Lawyers: Measuring Success in Family Court, 67 HastingS L.J. 1389, 1412 (2016); Michael Millemann, Nathalie Gilfrich, \& Richard Granat, Rethinking the FullService Legal Representational Model: A Maryland Experiment, 30 CleARINGHOUSE REV. 1178, 1185 (1997).

42 See Alyse Bertenthal, Speaking of Justice: Encounters in a Legal Self-Help Clinic, 39 Pol. \& LEGAL Anthropology Rev. 261 (2016); see Elizabeth L. MacDowell, Domestic Violence and the Politics of SelfHelp, 22 WM. \& MARY J. WOMEN \& L. 203, 272 (2016).

43 Tonya L. Brito, David J. Pate, Jr., Jia-Hui Stefanie Wong, 'I Do for My Kids": Negotiating Race and Racial Inequality in Family Court, 83 Fordham L. Rev. 3027, 3031-3033 (2015); Vicki Lens, Judge or Bureaucrat? How Administrative Law Judges Exercise Discretion in Welfare Bureaucracies, 86 Soc. SERV. REV. 269, 272-75 (2012).

44 John M. Conley \& William M. O'Barr, Fundamentals of Jurisprudence: An Ethnography of Judicial Decision Making in Informal Courts, 66 N.C. L. Rev. 467, 479-81 (1988).

45 Michele Cotton, A Case Study on Access to Justice and how to Improve it, 16 J.L. \& Soc'Y 61, 64 (2014).

46 See Barbara Bezdek, Silence in the Court: Participation and Subordination of Poor Tenants'Voices in Legal Process, 20 Hofstra L. REv. 533, 539, 583-90 (1992); Conley, supra note 44, at 468, 504; Cotton, supra note 45 , at 84-86; Lens, supra note 42 , at 280-83. 
and efficacy of experimental tribunals, such as problem-solving courts, have also been the subject of field study. ${ }^{47}$

The empirical studies that do exist provide important clues about the bearing of certain access to justice strategies on case outcomes. However, research on matters of access to justice policy is in its infancy, and there are substantial gaps in our knowledge about what does and does not work. We know little about the variation in how access to justice interventions are designed and implemented. We know little about how contextual factors such as court culture, substantive law, and judicial training influence case outcomes. And we know little about how parties navigate routine processes in local courts.

Former Chief Judge of the New York Court of Appeals Judith S. Kaye has lamented that: "Law school curricula are full of exciting new theories, doctrines, courses, and programs that push the frontiers of the law. But you don't see much about whether day-to-day court operations and administrative structures should also change, and if so, how .... . If we expect our legal system to remain vital and strong into the next century, we need advocates of change to think seriously not only about the exquisite nuances of the law but also about the hard reality of how our courts are functioning." 48

A small, dedicated, and entrepreneurial band of researchers has produced the knowledge we have on civil access to justice, but the field must broaden its reach if it aims to produce the depth and breadth of research truly necessary to inform policy, funding, and training for courtroom actors and service providers.

\section{LaW Schools Clinics as Sites for Civil ACCeSs to Justice Research}

Law school clinics are known for their dual teaching-service mission. 49 Traditionally, clinics represent low-income clients who would not otherwise have access to counsel while simultaneously training law students in the skills of practice and inculcating the value of public service. ${ }^{50}$ Recently, the idea that clinics might also be viable sites for important empirical research has been advanced. Jeanne Charn and Jeffrey Selbin have set forth a detailed proposal suggesting that law school clinics should serve as "lab offices" 51 that aim to produce knowledge about the civil justice system and the delivery of legal services—areas in which clinical law professors hold

47 See Jessica K. Steinberg, Informal, Inquisitorial, and Accurate: An Empirical Look at a ProblemSolving Housing Court, 42 LAW \& Soc. INQUIRY 1058 (2017); Jessica K. Steinberg, A Theory of Civil Problem-Solving Courts, 93 N.Y.U. L. Rev _ (forthcoming 2018)

48 Judith S. Kaye, Changing Courts in Changing Times: The Need for a Fresh Look at how Courts are Run, 48 HASTINGs L.J. 851, 852-53 (1997).

49 Charn, supra note 9, at 161; Colleen F. Shanahan, Jeff Selbin, Alyx Mark, Anna E. Carpenter, Measuring Law School Clinics, 92 Tulane L. Rev. 547, 551-59 (2018); Anna E. Carpenter, The Project Model of Clinical Education: Eight Principles to Maximize Student Learning and Social Justice Impact, 20 CLINICAL L. REV. 39, 51 (2013).

$50 \quad$ Jane Aiken \& Stephen Wizner, Teaching and Doing: The Role of Law School Clinics in Enhancing Access to Justice, 73 FoRDHAM L. REv. 997, 1008 n.41, n.42, 1008-09 (2004).

$51 \quad$ Charn, supra note 9, at 161. 
institutional expertise. ${ }^{52}$ This proposal dovetails with increased attention to the role that universities should play in generating academic research relevant to local communities and for the benefit of civil society. ${ }^{53}$

Charn and Selbin's proposal begins by acknowledging the dearth of civil justice research and the range of access to justice questions that remain unanswered. It then lasers in on law school clinics as potential sites for such research and names four reasons that clinics are well-positioned to take on a research function. First, clinics have "personal and positional capital." 54 They are directed by law professors with substantial exposure to race, poverty, and access to justice issues who can frame interesting and relevant research questions. As Charn and Selbin note, clinicians have direct, day-to-day experience delivering legal services, working in administrative tribunals, and litigating in local courts. Collectively, they have expertise in the full range of substantive areas comprising the civil justice system: housing, family law, consumer matters, and immigration, to name just a few. At the same time, the volume of service delivery in a clinic is typically low, particularly when compared to a civil legal services office, offering clinicians the opportunity to step back from practice and formulate theories and questions that can be tested in the field.

Second, clinics have access to data and expertise. ${ }^{55}$ Clinics are engaged in client service and have relationships with local communities and a range of justice actors. This regular and sustained engagement provides a unique vantage point for research and can often generate the access required to study a range of interesting issues, including civil justice needs, legal services delivery, and the institutions responsible for the administration of justice. Clinics are also typically located within research universities, creating opportunities to collaborate with social scientists who can play a range of roles in a research project. A social scientist collaborator may assist with research design, carry out the research in partnership with clinicians, or analyze and interpret data produced or collected by clinics.

Third, clinics enjoy institutional independence. ${ }^{56}$ Clinicians are relatively insulated from political interference and often have the freedom to establish their own case selection and service delivery systems. A clinician may decide to experiment with a new triage or lawyering model and then evaluate it. Or a clinician may decide to take cases under a newly adopted law and then study the enforcement process. This ability to innovate and experiment creates a fertile environment for research.

$52 \quad$ Id. at 162 .

53 See Frank O. Bowman, III, Days of Future Past: A Plea for more Useful and more Local Legal Scholarship, Legal Studies Research PAPER SERIES at 2, 39, 42 (2017); Jeffrey L. Harrison \& Amy R. Mashburn, Citations, Justifications, and the Troubled State of Legal Scholarship: An Empirical Study, 3 TeX. A\&M L. ReV. 45, 87-88 (2015); Our University's Mission, Vision, and Goals, UnIV. OF BufFalo, https://www.buffalo.edu/president/vision/mission-vision.html (last visited Nov. 19, 2017) (“The

University at Buffalo is a diverse, inclusive scholarly community dedicated to bringing the benefits of its research, scholarship and creative activity, and educational excellence to global and local communities in ways that impact and positively change the world.”). 
Last, empirical research has the potential to be a distinctive form of scholarship for clinicians. ${ }^{57}$ With increased job security for clinical law professors has come the expectation that clinicians produce research and scholarship.58 As participant-observers who can both engage with civil justice institutions and study them, clinicians have a unique perch from which to conduct empirical work. ${ }^{59}$ Although there can be structural disincentives to pursuing field research that must be overcome, 60 it can also have synergies with the service and pedagogical goals of the clinic that make it a natural fit for clinicians' background and expertise. ${ }^{61}$

Charn and Selbin's proposal is timely and connects to larger efforts by universities to engage with the local communities in which they are situated. ${ }^{62} \mathrm{In}$ particular, higher education has recently embraced community-based research (CBR) as a way to respond to critiques that universities are impervious to the plight of vulnerable populations living adjacent to campus. CBR espouses scholarship with relevance to the pressing social, economic, and environmental concerns of local communities. ${ }^{63}$ It seeks to broaden the reach of traditional academic scholarship, which is often theoretical in nature and disconnected from real-world application. To achieve its goals, CBR contemplates research collaborations between academics and local stakeholders that aim to maximize equality and social justice, and to

See id. at 163.

Jeanne Charn \& Jeff Selbin, Legal Aid, Law School Clinics and the Opportunity for Joint Gain, MGMT. INFO. ExCH. J. 28, 29 (2007).

Carrie Menkel-Meadow, The Legacy of Clinical Education: Theories about Lawyering, 29 CLEV. ST. L. REV. 555, 569, 572 (1980).

Deborah L. Rhode, Access to Justice: An Agenda for Legal Education and Research, 62 J. LEGAL EDUC. 531, 542 (2013), noting that one structural reason for low levels of access to justice research is that empirical work can have higher costs and lower rewards than traditional forms of scholarship. It requires a substantial investment of time, as well as the development of partnerships with social scientists-and may still be dismissed as "descriptive" scholarship. Andrea Boyack, Review: Law School Culture and the lost art of Collaboration, InstiTUTE L. TEACHING \& LEARNING,

http://lawteaching.org/2016/02/08/review-law-school-culture-and-the-lost-art-of-collaboration/ (last visited Nov. 18, 2017), noting that another structural disincentive is the expectation at many law schools that professors produce solo-authored work, rather than collaborative work. "A lower rate of collaboration reflects the legal academic culture that devalues co-written scholarship (for example, cowritten articles may receive only token credit towards tenure requirements).”.

Kaye, supra note 47, at 52-53 ("Law school curricula are full of exciting new theories, doctrines, courses, and programs that push the frontiers of the law. But you don't see much about whether day-today court operations and administrative structures should also change, and if so, how. Judges and court administrators are not the only ones that have noticed this dearth of attention to the mechanics of our justice system. One legal academic has written that he 'would happily trade a whole year's worth of the doctrinal output turned out regularly by smart law review editors and law teachers for a single solid piece describing how some court, agency, enforcement process, or legal transaction actually works.' . . . If we expect our legal system to remain vital and strong into the next century, we need advocates of change to think seriously not only about the exquisite nuances of the law but also about the hard reality of how our courts are functioning.").

David J. Maurrasse, Beyond the Campus: How Colleges AND Universities Form Partnerships with TheIR Communities 1 (2002) ("[C]ommunity partnerships such as this are happening at colleges and universities nationwide. A movement is emerging. University presidents are placing community partnerships higher on their agendas. Offices for community outreach are increasing their internal standing at colleges and universities, receiving bigger budgets and more exposure.").

See Strand, supra note 15, at 5. 
disseminate knowledge useful to the community. ${ }^{64}$ The mission statements of many universities now promote civic engagement, manifested both through servicelearning, such as law school clinics, and CBR. ${ }^{65}$ Charn and Selbin's "clinic lab office" is a concrete expression of how law schools might implement the aspirations of the CBR movement.

\section{The Court Watch: A Signature Research Method for Clinics?}

Building on Selbin and Charn's proposal, this Part advocates for the "court watch" as a signature research method for law school clinics. Most existing civil justice research has been conducted through surveys, interviews, and review of written case records. Although these methodologies offer valuable data and insights, there are many access to justice questions that can only be evaluated through live observation of court proceedings. ${ }^{66}$ Law professors do not often engage in field research of this variety because the labor involved is significant and there is neither a culture of grant funding within law schools, nor an obvious institutional mechanism for building a research team with graduate students. Clinical programs are not insulated from these challenges, but are perhaps better positioned than traditional law school courses to incorporate court watch research into their curricula as a form of student learning. This type of empirical work has the advantage of making a unique contribution to research, while also furthering the pedagogical goals of law school clinics. I will define court watch research and explore its untapped potential below before turning in Part IV to providing an example of a court watch project in action.

\section{A. What is a Court Watch?}

First, I answer two threshold questions: How do I define a court watch, and how might clinical law professors and students partake in such research? The term "court watch" is colloquial but refers to a serious form of field research undertaken in a naturally occurring environment: the courtroom. ${ }^{67}$ Despite the informal labeling,

64 See id.

65 Linda Smith, Fostering Justice Throughout the Curriculum, 18 GEO. J. PoverTy L. \& POL'Y 427, 437-41 (2011).

66 Anna E. Carpenter, Jessica K. Steinberg, Colleen F. Shanahan, and Alyx Mark, Studying the 'New' Civil Judges, Wis. L. Rev. (forthcoming 2018)

67 Sarah M. Buel, The Pedagogy of Domestic Violence Law: Situating Domestic Violence Work in Law Schools, Adding the Lenses of Race and Class, 11 AM. U.J. GENDER, Soc. PoL'Y \& L. 309, 349 (2003) ("By recording the behavior of judges and prosecutors on forms designed to reflect statutory requirements and minimal practice standards, students learn to evaluate complete cases. Court watches educate law students about the complex realities of the judicial system's handling of domestic violence cases."); Megan Griest, Monitoring the Law: Court Watch Programs in Maryland, 23 Annals Health L. 215, 224 (2014) ("Court watch programs are a way to monitor judicial behavior and report on its consistency in these cases.”); Leigh Goodmark, Telling Stories, Saving Lives: The Battered Mothers' Testimony Project, Women's Narratives, and Court Reform, 37 ARIZ. ST. L.J. 709, 751 ("Court monitoring, or court watch, 
court watch research, if done properly, is rigorous. Observers are trained, placed in a courtroom, and asked to record both qualitative and quantitative data in a formal collection instrument. The unit of study in a court watch is often the individual case hearing, but observers may also be asked to record data relevant to the courtroom environment that develops outside the bounds of the formal hearing.

In social science literature, court watch research may be labeled under different descriptors and methods, and thus the research cannot be easily coalesced into a coherent body of work. ${ }^{68}$ For instance, a court watch is often conducted as part of a focused ethnography, in which researchers seek to explore the "meaning which people draw from law-related events." 69 A court watch may be labeled more abstractly as "field research" or employed as part of a "mixed methods" study that triangulates its means through court observations, case file reviews, and interviews. ${ }^{70} \mathrm{In}$ fact, the term "court watch" is relatively absent from the academic literature and appears to be used primarily by advocacy organizations that engage in field observation to promote transparency and accountability within local courts. ${ }^{71}$ For purposes of this Article, I favor the term "court watch" over more academic labels for this research because of its accessibility and descriptive nature. It is important to our "datastarved" profession to use descriptors that promote inclusion in research. ${ }^{72}$

Although law professors are typically not trained researchers, they can collaborate with social scientists at their home institutions to design methodologically sound court watch research..$^{73}$ Most obviously, Ph.D. candidates in disciplines such as sociology, social work, political science, and public health may be interested in assisting with research design, coding, or analysis in exchange for payment, publishing credit, or access to data. Faculty members in other disciplines may also be interested in collaboration with law professors, as members of the legal academy offer access to, and knowledge of, the courts that cannot otherwise be easily obtained. Strategic partnerships across disciplinary fields can create an entrée into basic research that most law professors simply assume is out of their reach.

Even with interdisciplinary collaboration, however, the key to designing an effective court watch project is simplicity. Law students are not equipped to carry out complex data collection, especially within the confines of an academic semester. But, with training, they can certainly partake in courtroom observations and record

programs 'help the system reach its potential by identifying flaws, recommending solutions, and advocating for change' based on the cases that court monitors observe."). William M. O’Barr \& John M. Conley, Litigant Satisfaction Versus Legal Adequacy in Small Claims Court Narratives, 19 L. \& SoC'Y REV. 661, 673 (1985) (employing court observations to conduct a linguistic analysis of judge-to-party interactions).

69 Tonya Brito, Empirical Legal Research and the Urban Core, at 1, 17; see Lens, supra note 42, at 272275 .

$70 \quad$ Bezdek, supra note 45 , at 547-48.

71 See, e.g. WATCH MN, https://watchmn.org (a non-profit agency dedicated to court monitoring and judicial policymaking in Minneapolis).

72 Charn, supra note 9, at 168.

73 Id.; Anna E. Carpenter, Jessica K. Steinberg, Colleen F. Shanahan, and Alyx Mark, Studying the 'New' Civil Judges, WIS. L. REV. (forthcoming 2018). 
the presence or absence of a handful of variables. ${ }^{74}$ As described below, even a project with a narrow scope can contribute knowledge of use to the access to justice community.

\section{B. A Unique Contribution to Research}

Designed properly, court watch projects can advance our understanding of important civil justice issues that do not lend themselves to study in any other manner. They allow for observation of judicial conduct, litigant capacity, and decision-making processes that may not necessarily be visible from a review of a paper file. In addition, court watch projects permit a researcher to make objective assessments of the practices and behavior observed, without the filtering lens that is often a drawback of interviews. Finally, rigorous in-court data collection can confirm or disprove a practitioner's perception that a certain type of conduct is or is not occurring in court on a regular basis, which may help map the landscape of access to justice barriers.

To illustrate the potential impact of court watch projects, consider the following civil justice issues that would benefit from sustained in-court observation and published data.

Procedural due process. In the unanimous 2011 decision of Turner v. Rogers, the Supreme Court held that, in the absence of appointed counsel, courts are constitutionally required to implement "alternative procedural safeguards" to protect unrepresented child support contemnors. ${ }^{75}$ Such safeguards include, but are not limited to, active questioning of the unrepresented defendant on his sole affirmative defense: the ability to pay the child support debt. ${ }^{76}$ To date, the civil justice community has little to no information on whether and how courts are implementing the Turner mandate. ${ }^{77}$ Given the thin paper records typically maintained in child support proceedings and the unavailability of audio recordings or written transcripts, in-court observations may well be the only way to gather data on the courts' efforts to assist unrepresented defendants.

A range of questions related to Turner might be answered through a court watch project: Are courts actively seeking information on a defendant's ability to pay prior to making a finding of contempt on unpaid child support? If such information is being sought, which court actor is charged with this task: A judge? A clerk? A selfhelp advocate? How rigorously is the defendant's ability to pay evaluated in light of Turner's prescription? Are self-help forms or other written instruments utilized to

$74 \quad$ Faith Mullen (a law professor) and Enrique Pumar (a social scientist) offer a corollary to my proposal, describing how they trained law students in basic survey methodology as part of a larger empirical research project on access to justice in unemployment compensation cases. Enrique Pumar and Faith Mullen, The Plural of Anecdote is Not Data: Teaching Law Students Basic Survey Methodology to Improve Access to Justice in Unemployment Insurance Appeals, 16 U.D.C. L. Rev. 17 (2013). Id. at 448 .

76 See id. at $431,447-48$.

77 But see Elizabeth Patterson, Turner in the Trenches, A Study of How Turner v. Rogers Affected Child Support Contempt Proceedings, 25 Geo. J. Poverty L. \& Pol'y (2017). 
elicit information from the defendant, or do judges rely on oral colloquy?78 Data could be used to bring non-conforming courts into compliance with Turner and to promote a meaningful review of the ability-to-pay standard, particularly on the issue of the defendant's imputed income. Data could also be used to unearth, refine, and scale best practices through a peer review mechanism. Courts have little opportunity to learn from one another, in part because little data is publicly available and few information sharing systems exist. ${ }^{79}$

Default judgments. A major access to justice barrier in the civil courts involves the high number of cases resolved by default judgment. This is particularly a problem in consumer cases, where the Federal Trade Commission has reported default rates as high as sixty to ninety percent. ${ }^{80}$ Default judgments are troubling because they appear on credit reports and can have substantial implications for a person's stability and financial security - and yet they may not be based on any proffer of evidence from the prevailing party. Human Rights Watch has expressed grave concerns over the cavalier manner in which judges appear to enter default judgments against debtors, sometimes entering hundreds of orders in a single day. 81

Even with growing evidence that consumer protection is given short shrift by the courts, little is known about the way in which judges manage defaults or issue orders. In the consumer setting, a court watch project could uncover important elements of this process: Do judges require creditors seeking default judgments to appear in court, testify, or produce evidence? Are creditors' claims carefully interrogated or merely rubber-stamped? Are procedural preconditions to default judgments, such as service of process, rigorously enforced by judges? Observations of default hearings could be instrumental in both advancing consumer rights and understanding an elusive and hidden component of the civil adjudication system.

Victim safety. In the domestic violence arena, advocates have sought to hold courts accountable for protecting victims' safety and rights. A number of best practices have been developed to promote this goal, including staggering the parties' exits from court, permitting victims to offer a written statement in lieu of oral testimony, and connecting victims to a range of social service providers and lay advocates who may assist with both the court process as well as collateral needs such as safe housing.

Domestic violence advocates are already utilizing court watch research effectively and systematically to identify ways in which courts may be compromising

78 For a critique of the use of forms in establishing indigency, see Andrew Hammond, Pleading Poverty in Federal Court, Yale L. J. (forthcoming 2018).

79 Carpenter, supra note 17.

80 See Fed. Trade Comm'n, Repairing a Broken System: Protecting Consumers in Debt Collection LitiGATION AND ARBITRATION 7 (July 2010) (reporting that most panelists involved in roundtable discussions about the "broken" debt collection system indicated that "the [default] rate in their jurisdictions was close to ninety percent”); see also SusAn SHIN \& ClaUdia WiLner, New Economy Project, The Debt Collection Racket in New York: How the Industry Violates Due Process and Perpetuates Economic Inequality 6 (Sarah Ludwig \& Josh Zinner, eds. 2013) (reporting that eighty percent of default judgments in New York State arose from consumer cases).

81 See Chris Albin-Lackey, Human Rights Watch, Rubber Stamp Justice: Us Courts, Debt Buying CorPorations, AND THE POOR 3-4 (Arvind Ganesan et al. eds., 2016). 
victim safety, dignity, and voice. One project, in Cook County, Illinois, was implemented by 100 volunteers who collectively viewed 7,000 cases and found that, in some courtrooms, judges took lengthy and unexplained breaks and were unprepared for cases, sending a message to litigants that their cases were unimportant. ${ }^{82}$ Observers further noted that judges did not consistently connect victims with available safety advocates or coordinate service of process with the police department. ${ }^{83}$ The project also discovered evidence that judges were not fully utilizing the range of remedies available through the state's civil protection order statute, ultimately denying victims the full benefit of authorized relief. ${ }^{84}$ The project made several specific recommendations to the court about ways to improve case management, as well as the accountability of their services. ${ }^{85}$ The Cook County project demonstrates concrete benefits to court watch research in advancing broad justice system goals. Without the regular in-court presence of a fleet of volunteers trained to record data, many of the flawed mechanics of civil protection order proceedings would have been undetected or unprovable.

Lopsided representation. For both courts and litigants, lopsided representation represents a particular challenge in today's civil justice system. ${ }^{86}$ In such cases, one party has counsel and the other does not, and often the lopsided representation favors the party who already occupies the relative position of power and wealth. ${ }^{87}$ Housing is an area particularly plagued by lopsided representation, with the vast majority of landlords appearing with counsel, and the vast majority of tenants appearing pro se. ${ }^{88}$ Judges can find it difficult in these cases to balance competing interests. They must find ways to adhere to adversary norms while ensuring fairness, all within the setting of a high-volume caseload. ${ }^{89}$

Housing advocates have long reported that judges may privilege efficiency over fairness in troubling ways, particularly in lopsided representation matters. ${ }^{90}$ Existing reports suggest that judges may direct tenants into the courtroom hallway to negotiate eviction settlements with represented landlords or that judges may ask a landlord's attorney to explain law or procedure to lay tenants off the record. ${ }^{91}$

A court watch project might help determine whether such judicial choices are pervasive or irregular. Live observations of eviction proceedings would also provide

See Chi. Metro. Battered Women's Network, Working Together to End Society's Tolerance of Domestic Violence: Court Watch Report July 2012-June 2013, at 10 (2013).

See id. at 12 .

84 See id. at 18.

For another example of a court watch project that uncovered important issues related to victim safety, see DC Coal. Against Domestic Violence \& Survivors \& Advocates For EMpowerment (SAFE), DC COURT WATch ANNUAL RePorT: Fiscal YeAR 2006 (2006).

86 Jessica K. Steinberg, A Theory of Civil Problem-Solving Courts, 93 N.Y.U. L. Rev. (forthcoming 2018)

87 See Steinberg, supra note 23, at 921-22; Colleen F. Shanahan, Anna E. Carpenter, \& Alyx Mark, Lawyers, Power, and Strategic Expertise, 93 DENV. L. REV. 484, 505-06 (2016).

See Steinberg, Demand Side Reform, supra note 2, at 750.

See Steinberg, supra note 2.

See Steinberg, supra note 23, at 899, 940.

See Russell Engler, Out of Sight and Out of Line: The Need for Regulation of Lawyers' Negotiations with Unrepresented Poor Persons, 85 CAL. L. REV. 79, 121, 146 (1997); Erica L. Fox, Alone in the Hallway: Challenges to Effective Self-Representation in Negotiation, 1 HARV. NEGOT. L. REV. 85, 91-92 (1996). 
information on how judges adjudicate hearings in which one party is pro se. Does judicial behavior in such cases comport with the passive norm expected of judges in the adversary system? Or are judges active in assisting unrepresented parties? Will a judge, for instance, intervene on behalf of a pro se tenant to object to the admission of prejudicial evidence? Will a judge assist a pro se tenant with cross-examination? How do judges seek buy-in from both parties regarding alternative procedures to be used in lopsided cases? Is it the landlord or the judge who appears to be controlling the process and defining the issues in such matters?

In short, there are countless civil justice issues that would benefit greatly from a court watch. Such research can be narrowly tailored to tackle just one aspect of a larger question and still make a significant contribution. Field data can inform policy changes, lead to rule revisions, and influence funding decisions on access to justice interventions. In an environment where important policy decisions are made every day in the absence of data, any well-constructed field project, no matter how simple its aims, will yield information of value.

\section{Pedagogical Benefits}

Embedding research into a clinical program offers significant pedagogical benefits that complement and enhance the traditional lawyering skills clinics aim to impart. This Part suggests four distinct pedagogical advantages of incorporating a court watch project into a clinic alongside individual client representation or projectbased work. First, a court watch instills the professional value of service by exposing students to a broad swath of justice issues. Second, observations of courtroom actors can acculturate law students to the norms and habits of lawyers and judges, much in the way that the "see one" pedagogy of medical schools promotes observation of a procedure prior to performing it. Third, field research develops the context necessary for students to interrogate the nature and purpose of their individual client work in a deeper manner. And finally, court watch projects offer a method for teaching students, in an experiential manner, how to critique and design institutional systems.

\section{i. Inculcating the Value of Service}

In an influential 2007 report on the state of legal education, the Carnegie Foundation criticized law schools for failing to develop in students a strong sense of professional identity. ${ }^{92}$ Calling it the "third apprenticeship" after theory and skillbuilding, the Carnegie Report found that professional identity formation was not a sufficiently emphasized aspect of law school training. ${ }^{93}$ The Carnegie authors

92 The Carnegie Report termed formation of professional identity the "third apprenticeship" (after "theory" and "skills") and found law school education most lacking in this area. WilLIAM M. SulLIVAN, Anne Colby, Judith Welch Wegner, Lloyd Bond, \& Lee S. Shulman, The Carnegie Foundation for the Advancement of Teaching, Educating LaWyers: Preparation for the Profession of Law 28 (2007).

$93 \quad$ See id. at $129-135$. 
identified a range of ethical and social values that should be taught as part of professional identity and suggested that the legal profession risks "loss of a moral compass"94 if law schools do not expand curricular instruction on ethical responsibilities such as service to others. ${ }^{95}$

Commentators have echoed the recommendations of the Carnegie Report and proposed that law schools infuse the curriculum with social justice concerns. ${ }^{96}$ Deborah Rhode has been a leading voice in this area and has repeatedly exhorted law schools to socialize the next generation of lawyers to serve as public citizens and to take advantage of the "unique opportunity and obligation to make access to justice a more central social priority." 97 Jane Aiken and Steven Wizner have argued that clinicians have a special obligation to cultivate a profession that embraces a responsibility to ensure access to justice for the poor and should strive to inculcate in students "compassionate concern for the plight of people living in poverty." 98

Court watch projects offer a novel way to expose law students to a broad swath of justice issues and to advance professional identity learning goals. Law students can learn a tremendous amount about "what passes for justice among the have nots" by observing court proceedings. ${ }^{99}$ Clinics, of course, are already deeply steeped in these efforts, and the work of representing individual clients does much to instill the value of service. However, almost by definition, the traditional clinical teachingservice model only offers students a window into how rights are enforced and developed when an attorney is involved. Field observation is a productive and beneficial means by which to encourage students to (re)consider how the justice system does and does not live up to the challenge of offering equal access to justice when lawyers are not present.

\section{ii. "See One" Pedagogy}

In addition to instilling moral values in law students, the Carnegie Report also emphasizes the need for law schools to acculturate burgeoning young lawyers to the norms and habits of the profession. 100 The authors note that legal education relies too heavily on the case-dialogue method, "conveying the impression that lawyers are

$94 \quad$ Id. at 140.

95 See id. Speaking to the importance of professional values within the law school curriculum, the Carnegie authors assert that: Law school experiences, if they are powerfully engaging, have the potential to influence the place of moral values such as integrity and social contribution to the students' sense of self ... Because law school represents a critical phase in the transition into the profession, it is inevitable that it will influence students' image of what kind of lawyers they want to be ...... [F]or students to incorporate the profession's ethical-social values into their own, they need to encounter appealing representations of professional ideals, connect in a powerful way with engaging models of ethical commitment within the profession, and reflect on their emerging professional identity in relation to those ideals and models.

96 See Linda F. Smith, Fostering Justice Throughout the Curriculum, 18 GEO. J. ON PoverTy L. \& PoL'Y. 427, 432 (2011).

97 Deborah L. Rhode, Access to Justice 193 (2004).

$98 \quad$ Aiken, supra note 49, at 1011.

$99 \quad$ Rhode, supra note 58, at 532.

100 See SULLIVAN ET AL., supra note 88, at 128. 
more like competitive scholars than attorneys engaged with the problems of clients."101 The result is that students receive little training as apprentice practitioners and little instruction on the "social and cultural contexts of legal institutions and the varied forms of legal practice."102

In medical school, professional practice skills are taught in accordance with the "see one, do one, teach one" pedagogy. 103 The basic thrust of this method is that students first observe a procedure, then conduct the procedure, and finally teach another trainee how to perform the procedure.104 By escalating the degree of responsibility in this way, students have the opportunity to learn through observation before assuming the burden of capably performing a task on their own. Christine Coughlin makes the case that the "see one" element of the medical school pedagogy would be a particularly valuable addition to legal education. ${ }^{105}$ As she notes, seasoned attorneys routinely employ the "see one" technique in practice, beginning with samples when drafting a new document or observing proceedings before entering an unfamiliar courtroom - and yet legal education does not offer any exposure to this component of the sequence. 106

Student involvement in court watch research offers some of the benefits of the "see one" pedagogy. At its most elemental level, a court watch provides students with the opportunity to observe litigants, lawyers, and judges at work, thereby internalizing the norms of courtroom practice. Coupled with the type of structured reflection I describe, infra, in Part IV, student observations can be appropriately contextualized and connected to larger lawyering lessons. ${ }^{107}$ Through "see one"-style observation, students might gain insight into the tactics that succeed or fail in a particular setting, or develop the building blocks of the personal lawyering style they hope to mimic in practice. ${ }^{108}$ Perhaps more fundamental to the work of a good lawyer, courtroom observations also promote "[t]he ability to judge day-to-day law practice against objective standards of justice and fairness." 109 There are surprisingly few opportunities in law school for students to develop the intangible skill of exercising good judgment, and a court watch supports the acquisition of knowledge critical to this process by engaging the obvious first step: plain and simple observation.

\footnotetext{
$101 \quad$ Id. at 188.

$102 \quad$ Id. at 56-57, 188.

103 Daniel B. Jones, Kinga A. Powers, \& Scott T. Rehrig, A New Paradigm for Surgical Training, CRICO ForUm (Jan. 2008), https://www.rmf.harvard.edu/Clinician-Resources/Article/2008/A-New-Paradigmfor-Surgical-Training.

104 See Sandra V. Kotsis \& Kevin C. Chung, Application of See One, Do One, Teach One Concept in Surgical Training, 131 Plastic \& ReConstructive Surgery 1194, 1194 (2013).

105 See Christine N. Coughlin, Lisa T. McElroy, \& Sandy C. Patrick, See One, Do One, Teach One: Dissecting the Use of Medical Education's Signature Pedagogy in the Law School Curriculum, 26 GA. ST. U. L. REV. 361, 379-87 (2010).

106 See id. at 387.

107 See infra Part IV.

108 See infra Part IV.

109 Robert J. Condlin, "Tastes Great, Less Filling”: The Law School Clinic and Political Critique, 36 J. LEGAL EDUC. 45, 50-51 (1986).
} 
Changes in the legal profession over the past decade make it particularly important that students observe and understand the legal needs of low- and middleincome individuals. Raymond Brescia has made the important point that access to justice concerns should occupy a central role in the law school curriculum because many of the jobs available to graduating students may involve people of limited means. ${ }^{110}$ Emily Spieler adds that law students need to think critically about innovative ways to serve this population in order to address a stubborn market paradox: the mismatch between the "glut" of unemployed law graduates and the enormous unmet legal need that exists in many American communities. ${ }^{111}$ A court watch project offers a vehicle for law students to digest the reality of legal practice in the trenches of our lower courts. Structured observation in a setting where most individuals do not have lawyers may catalyze students to consider how technology, brief service models, and low-bono fee structures might combine to create alternative practice models that are not typically explored in law school. 112

\section{iii. Interrogating the Nature and Purpose of Individual Client Work}

Through a system of self-evaluation and reflection, clinics encourage students to consider the impact and unintended consequences of their lawyering choices. ${ }^{113}$ This pedagogical approach has important advantages in helping students learn to make sound strategic choices, critically evaluate their actions, and develop a nuanced approach to practice that develops iteratively. ${ }^{114}$ Most student reflection in clinics arises, naturally, out of the core work of clinical programs-individual client representation-and examines the attorney-client relationship as well as the lawyer's engagement with legal institutions. ${ }^{115}$ A court watch offers a complementary vehicle for interrogating the nature and value of a lawyer's work in a deeper manner.

For one, field observation can challenge students' assumptions about the power and purpose of their work. For instance, clinical students often think of a lawyer's work in heroic terms, especially when a legal victory is secured for a client. Students may fail to understand the difficulty of enforcing a paper judgment, or may overestimate the power of a legal ruling to alter the conduct of bad actors. They may also fail to appreciate that a legal victory does not always represent an unabashed improvement to a client's lived experience. Through a court watch, students may observe litigants who have repeatedly returned to court to seek the same relief over and over again from a noncompliant opponent. They may observe individuals who

\footnotetext{
110 See Raymond H. Brescia, When Interests Converge: An Access-to-Justice Mission for Law Schools, 24 GeO. J. ON Poverty L. \& PoL'Y 205, 224-28 (2017).

111 See Emily A. Spieler, The Paradox of Access to Civil Justice: The "Glut" of New Lawyers and the Persistence of Unmet Need, 44 U. TOL. L. REV. 365, 394 (2013).

112 See Mitch, Tipping the Scales of Justice: The Role of the Nonprofit Sliding Scale Law Firm in the Delivery of Legal Services, 20 NYU J. LEGIS. \& PUB. POL'Y 375, 378, 401 (2017).

113 See Amy L. Ziegler, Developing a System of Evaluation in Clinical Legal Teaching, 42 J. LEGAL EDUC. 575, 577-78 (1992).

114 See Timothy Casey, Reflective Practice in Legal Education: The Stages of Reflection, 20 CLINICAL L. REV. 317, 321 (2014).

115 See generally Zielger, supra note 110.
} 
have lost their jobs or become estranged from family members due to an ongoing legal matter. They may observe individuals who have become ensnared in the justice system despite having successfully fended off prior lawsuits. These observations can promote a deeper appreciation of the limits of the lawyer's role and may encourage students to think critically about other ways to agitate for social justice.

In addition, court watch research can broaden a student's perception of the lawyer's role. Clinical students often conceive of the lawyer's role narrowly, placing the greatest value on a lawyer's ability to analyze doctrine and present legal arguments. Students may not consider alternative goals for legal representation, such as promoting dignity or voice. Field observation is a particularly powerful way to introduce students to the experiences of unrepresented litigants in court and to raise the notion that legal representation may also locate part of its value in promoting procedural justice. In court, unrepresented litigants often appear bewildered and overwhelmed. They may be silenced by a judge or have their actions dismissed for overly complex technical reasons without an opportunity to share their story. In observing such matters, students may reflect on the value of a lawyer's role in shaping a narrative and promoting client voice-even if the ultimate outcome is unfavorable.

\section{iv. Systems Design and Critique}

A final pedagogical advantage of court watch research is that it encourages students to engage in systemic critique and reflect on the design of legal roles and institutions. Carrie Menkel-Meadow has embraced the view that institutional critique is a "macro" goal of clinical education whereas skills acquisition is a "micro" goal.116 Robert Condlin articulates a similar vision for law schools more broadly, naming "critique" as the university's "highest function" and suggesting that "the obligation to pursue critique is heightened not diminished by the fact that law school is the last step on a journey into a profession." 117

Endorsing these views, I suggest that field observation provides fodder for a clinical professor to guide students through thoughtful discussion of a range of important systemic questions: Do judges and other court actors comport themselves in expected ways? What institutional pressures are influencing their choices? Does the observed tribunal produce at least a rough justice and how do we evaluate that? What are the access to justice barriers faced by litigants and how are they being addressed? How should systems and roles be reformed to respond to the challenges students observe?

Court observations are likely to fill students with a sense of surprise and wonder about what they did not know. ${ }^{118}$ Many of a courtroom's familiar features-a packed

116 Menkel-Meadow, supra note 57, at 556-57.

117 Condlin, supra note 109, at 51.

118 Sarah Buel highlights how court watch projects can focus student attention on the logistical, behavioral, and legal challenges that clients experience in court, all of which may motivate students to engage in thoughtful critique of our justice system: 
gallery, trials that last no longer than two minutes, troubling race and class dynamics, a lack of formal procedures, rushed settlements hammered out in the hallway - are unknown to students and not so easily taught in a classroom setting. A court watch can surface these issues and create the setting for group thinking on structural critique. Moreover, it can offer this experience across all students enrolled in a law school clinic. This type of shared learning process, where students have the opportunity to think about and work on the same problem, is difficult to create in an experiential curriculum. A common base of knowledge and experience, such as that created by court watch research, helps students build camaraderie and professional relationships and enables them to challenge one another effectively in classroom discussion.

\section{The Court Watch in ACtion}

Having discussed the research and pedagogical benefits of court watch projects, I turn now to a discussion of how a court watch might be implemented in the clinic setting. I use, as an example, a court watch project I incorporated into my own clinic at The George Washington University Law School over the course of two semesters. ${ }^{119}$ Drawing on this experience, I offer four principles to consider in designing an effective court watch project for clinic students.

\section{A. The $G W$ Project}

Although law school clinics may well formulate their own research questions, the court watch project I conducted in my clinic was launched at the behest of a local legal services provider. The provider was interested in evaluating the operation of a

\footnotetext{
"I began requiring court watches upon realizing that most law students have never set foot in a courthouse, and neither know how to find one nor know what is supposed to happen inside. The process of simply locating the correct courthouse and courtroom, and finding parking or public transportation, helps students better understand the obstacles faced by [domestic violence] victims attempting to access the judicial system. Scrutinizing the treatment of victims by key players, from clerks and lawyers to judges and security staff, allows students to witness the disparity between enactment of legislation and its implementation. Students are also taught to follow the treatment ordered for perpetrators, and, in so doing, gain a better understanding of the potentially conflicting interplay between efforts at reform, punishment, and deterrence."
}

Buel, supra note 64 , at 349 .

119 The clinic is now named the Prisoner \& Reentry Clinic, but at the time of the court watch was named the Neighborhood Law \& Policy Clinic, see GW LAW, https://www.law.gwu.edu/prisoner-reentry-clinic (last visited Jan. 27, 2018). 
new and experimental court, yet lacked the resources to maintain a regular presence in the tribunal-creating an opportunity for synergistic collaboration with a clinic. ${ }^{120}$

The court watch was implemented over the course of two clinical semesters. Judges were advised of the project, and in advance of the semester, I developed a rough data collection instrument in partnership with the legal services provider. At the outset of the semester, I instructed students on the substantive law of the court, and then accompanied students to court to train them on data collection protocols.

The first semester of the project constituted the "pilot" phase. Each student visited court twice and observed proceedings in two-hour blocks. At the conclusion of the semester, we had collectively observed more than 200 hearings. This pilot phase enabled us to learn more about the court, observe a sufficient range of cases, and create a more finely tuned data collection instrument that would capture the nuances of the court's operation.

In the second semester, we commenced formal data collection and followed a similar process. Students observed court proceedings in two-hour blocks, with each student visiting the court twice during the course of the semester. After each observation, students logged their data into a coding sheet. At the end of the semester, the students worked together to analyze the data and prepare a final report. The report was ultimately presented to our community partner.

The court watch offered abundant opportunities for student reflection, and two clinic seminar sessions were set aside each semester for discussion. Students were provided with discussion questions to ponder in advance of class and were asked to consider a range of topics. First, students reflected on consistency and accuracy in data collection. Was it possible to ensure uniformity in student observations? Would all judicial actions be interpreted similarly by different students? How might we account for discrepancies in our reporting? Second, students discussed the roles of various court actors. Did institutional actors operate in familiar or unfamiliar ways? Was judicial discretion exercised fairly or unfairly? Were lawyers present in the courtroom and how did they influence proceedings? Finally, the students focused on the nature of justice. What process features are associated with justice and were they observed? How might we evaluate whether justice has been achieved? Is a lawyer necessary to achieve it?

It is important to recognize that these reflections are not in the exclusive domain of court watch research; similar discussions can also be generated through individual case work. However, the primary pedagogical focus of direct representation is skill development and the attorney-client relationship. The court watch is an effective and complementary vehicle for reflection, in that it has the express purpose of complicating students' perceptions of and reactions to the justice system more broadly. and clinics); Anna E. Carpenter, The Project Model of Clinical Education: Eight Principles to Maximize Student Learning and Social Justice Impact, 20 ClinICAL L. REv. 51-52 (2013). 


\section{B. Principles for Conducting a Court Watch}

Although I can imagine many methodologically and pedagogically sound approaches to court watch research, I offer four principles that have been useful in my own implementation.

Design modest research goals. The project described above focused on a handful of simple research questions that were relatively easy to answer through observation. Clinical professors are accustomed to devising case work that can accommodate and yet challenge a student's skill level. Similarly, court watch projects must be designed with the proper scope and objectives to enable successful student participation. So little is known about our civil justice system that even a small, well-designed study has the potential to contribute high-value knowledge to policymakers and advocates.

Consider partnerships with outside agencies. Clinical programs have expertise in certain fields and tribunals, and can often generate interesting research questions on their own. However, it can be politically problematic to conduct research in a forum where one is also functioning as a lawyer. Community partners may have research needs at the ready that clinics can implement in substantive areas outside their normal operations. Partnerships may also amplify the impact of the court watch, particularly where the partnering agency has the capacity and intention to utilize the data in advocacy efforts. Finally, a community partner can function as an organizational client, creating opportunities for students to couple court watch research with the development of basic lawyering skills: eliciting client goals, drafting a Memorandum of Understanding to define the parameters of the partnership, and presenting findings in a formal report. Challenges can arise in terms of determining who owns the data and how it is utilized, but a community partnership remains an innovative model worth exploring.

Take time to develop a data collection instrument. Especially when conducting research in an unfamiliar tribunal, it can take many months to develop an effective data collection tool. This process does not have to be shouldered by the clinical professor in advance of the semester; it can be conceived of as a clinic project in and of itself. A pilot phase is an important part of data collection and introduces students to the complexity of capturing data accurately in a live environment. Undertaking the process of developing a data collection instrument will make students more sophisticated consumers and analyzers of data in the future-an increasingly important part of legal practice.

Incorporate reflection. Do not underestimate the power of simple observation. Students are often stunned by what they see in court and eager to process their observations. In the semesters I conducted court watch research, students were able to engage in highly sophisticated discussion about the failings of our justice system. Following structured reflection, I invited the presiding judges of the targeted court to speak to the class and respond to student observations. These reflection sessions were among the liveliest of the semester and offered the most effective teaching vehicle I have yet encountered for exposing students to systemic access to justice concerns. 


\section{CONCLUSION}

Court watch projects offer the potential to serve as a signature research method for law school clinical programs. Court watch research is realizable within the clinical setting and presents a valuable format for collecting data of use to the community. These projects capitalize on the lawyer's particular expertise by focusing on live observation of legal proceedings and legal actors. They also contribute to our empirical understanding of civil justice systems and advance clinics' teaching and service goals without supplanting individual representation as the core clinic pedagogy. And they provide a vehicle for reflection and assessment of structural access to justice concerns.

Selbin and Charn detail a number of challenges attendant to conducting research in the clinical setting, all of which must be taken seriously. First, clinicians must be wary of encroachments on their service and teaching activities. Second, collaboration with social scientists is critical as clinicians are not trained in rigorous research methods. Third, clinicians must be cognizant not to over- or undergeneralize their findings. Fourth, clinicians must be attuned to stakeholder resistance to research and able address concerns about the potential negative implications of data. And finally, clinicians need to think about how to bolster the inclusion of client perspectives and needs in research design. ${ }^{121}$

However, even recognizing these challenges, law school clinics are uniquely positioned to make a contribution to research. As a thought experiment, imagine that every law school clinic in the country opted to collect data responsive to just a single research question. The sum total of the knowledge accrued would be enormous. Law school clinics could be leaders in gathering data to help us better understand our courts, our administrative systems, our judges, and our legal professionals. The impact would be even greater were clinics not to operate as siloes, but rather collaborate on collection and dissemination of data across jurisdictions-a prospect that could be realized given the strong professional ties and associations that exist among clinicians nationwide. 